\title{
Screening of the Physico - Chemical Parameters of Essential Oil Aegle marmelous from Dang District of Nepal
}

\author{
Khuma Sharma Dhital* \\ Department of Chemistry, Patan Multiple Campus, Tribhuvan University, Nepal \\ Email:khumadhital@gmail.com
}

\begin{abstract}
Aegle marmelos leaves are used as anti-diabetes agent in Ayurveda, Unani \& Siddha Systems of Medicine. The essential oil of fresh leaves of Bael (Aegle marmelous) was isolated by hydro-distillation method using Clevenger apparatus and the oil percentage was $1.1 \%$. Aegle marmelos leaves wild variety from dang district forest were analysed for Specific Gravity, Refractive Index, Optical Rotation, Acid Value and Ester Value. Specific gravity is 0.93 at $20{ }^{\circ} \mathrm{C}$; Refractive index is 1.534 at $25{ }^{\circ} \mathrm{C}$, Optical rotation $-0.09^{\circ}$ at $23{ }^{\circ} \mathrm{C}$, Acid Value 2.4 and Ester Value 17.7.
\end{abstract}

Key Words: Bael, Fresh leaves, essential oil, physic-chemical parameters

\section{Introduction:}

Aegle marleous in Nepali Bael belongs to family Rutaceae is moderate sized, selender aromatic tree, 6.0-7.5 m in height, and 90-120 cm grith growing as a deciduous forest in sub-tropical region in Nepal ${ }^{1,2}$. Various rhamnopyranoside ${ }^{3}$, anthraquinone, aegeline, lupeol, cineol, citral and eugenol are isolated from the leaves of the tree ${ }^{4}$. The leaves and fruit are commonly useful as essential drugs in gastrointestinal disorder ${ }^{5}$. Leaf contains active ingredients can be used in metabolic syndrome and use this plant as alternative add-on medication ${ }^{6,7}$.

The essential oils are natural products that exhibit a variety of biological properties, such as analgesic anticonvulsant and anxiolytic. In this paper, physico of the leaves of the A. marmelos was studied and estimated.

\section{Experimental Methods}

Fresh leaves of Aegle marmaleous were collected from Dang district located in Mid-western Development Region of Nepal in May 2017. Collected fresh leaves were hydro distilled in a Clevenger apparatus for six hours. The yield of essential oil was $1.1 \%$. The oil thus obtained was dried over anhydrous sodium sulphate and stored in a sealed glass vial at low temperature prior to analysis.

\section{Determination of the percentage essential oil of the Aegle marmelous}

$100 \mathrm{gm}$ sample taken into distillation flask and add distilled water into it about sink of sample and add a few pieces of porous porcelain into distillation flask. Join the flask with graduated clevenger filled with distilled water up to level, join the condenser. The flask is heated until boiling begins and then lower the

${ }^{*}$ Corresponding author 
temperature at $50-60^{\circ} \mathrm{C}$ and continue the heating upto 4-6 hours. Stop heating and take the volume of oil after 10 minutes.

\section{Determination of the optical Rotation of the Aegle marmelous}

The optical rotation of an essential oil is the angle in which plane polarized light is rotated by oil at a specified temperature. A polarimeter is used for the determination of the optical rotation. $100 \mathrm{~mm}$ tube is used for measuring the optical rotation of the essential oil. The polarimeter tubes is taken out of the cell and pour the essential oil in it till its neck ensuring there is no air bubble in it. Place the polarimeter tube in the cell and press the measure key to note the reading.

\section{Determination of the Refractive index of the Aegle marmelous}

The refractive index is the ratio of the sine of the angle of incidence to the sine of angle of the refraction when a ray of light passed into the essential oil kept at a constant temperature. In Abbe Refractometer the liquid sample is sandwiched into a thin layer between an illuminating prism and a refracting prism. The range of Abbe refractometer is 1.300 to 1.700. Samples with different refractive indexes will produce different angles of refraction and this will be reflected in a change in the position of the borderline between the light and dark regions. By calibrating the scale, the position of the borderline can be used to determine the refractive index of any sample.

The reference temperature is $20^{\circ} \mathrm{C}$, except for those oils which are not liquid at this temperature. In this case, a temperature of $25^{\circ} \mathrm{C}$ or $30^{\circ} \mathrm{C}$, depending on the melting point of these essential oils, should be used. Place a few drops of test sample on prism. Close prisms firmly by tightening screw head. Bring this border line into field of vision of telescope by rotating double prism by means of alidade and note the reading on corresponding temperature by using scale.

\section{Determination of the Specific gravity of the Aegle marmelous}

The specific gravity was measured by specific gravity bottle Pyknometer method. The weight of the given volume of the liquid at desired temperature is determined in specific gravity bottle previously calibrated at same temperature. Specific gravity is the ratio of the density of the oil with that of the reference substance taken as water.

Weigh specific gravity bottle with distilled water and carefully insert stopper avoiding any air bubbles. Allow to stand for 30 minutes to acquire room temperature. Remove water droplets outside the bottle by tissue paper. Weigh specific gravity bottle with water, empty the bottle and rinse several times with alcohol and dry completely and weigh bottle with stopper. Fill bottle with test sample and repeat the process as above for the water.

The specific gravity was measured at temperature $20 \pm 5^{\circ} \mathrm{C}$.

$$
\text { Specific gravity }=\mathrm{W}_{\text {test sample }} / \mathrm{W}_{\mathrm{H} 20}
$$

Where, $\mathrm{W}_{\text {test sample }}=$ Weight of specific gravity bottle with test sample- weight of empty specific gravity bottle.

$\mathrm{W}_{\mathrm{H} 2 \mathrm{O}}=$ Weight of specific gravity bottle with water- weight of empty specific gravity bottle. 


\section{Determination of the Acid Value of the Aegle marmelous}

Acid value is determined by acid base titration method. The acid value of an essential oil is the number of milligrams of potassium hydroxide required to neutralize the free acids contained in $1 \mathrm{~g}$ of the essential oil. Essential oil is dissolved in alcohol-ether mixture and titrated with standard alkali.

Standardization of $\mathrm{KOH}$ by Potassium hydrogen phthalate:

Accurately weigh $0.2 \mathrm{~g}$ of moisture free potassium hydrogen phthalate and transfer into conical flask. Dissolve in distilled water $(25 \mathrm{~mL})$. Add Phenolphthalein as indicator and Titrate with standard alcoholic $\mathrm{KOH}$ solution till a pink color (which persists for more than 1 second) is observed. Note the volume of $\mathrm{KOH}$ consumed.

\section{Determination of Acid Value}

Weigh about $2 \mathrm{~g}$ of sample of essential oil in conical flask. Add $5 \mathrm{ml}$ of neutralized ethanol and swirl it slowly till sample dissolves in the solution. Add 5 drops of Phenolphthalein. Titrate with standard ethanolic $\mathrm{KOH}$ from burette till a faint pink color (which persists for more than 30 seconds) is observed. Note the volume of $\mathrm{KOH}$ consumed.

\section{Method of Calculation:}

Standardization of $\mathrm{KOH}$ by Potassium hydrogen phthalate

$$
\text { StrengthofKOH }=\frac{\text { Weight of Potassiumhydrogenphthalate }(\mathrm{PHPh}) \text { taken }}{\text { Volume of KOHconsumed } \mathrm{x} \text { Molecularweight of PHPh }} 1000
$$

Determination of Acid Value

$$
\text { AcidValue }=\frac{56.11 \mathrm{X}(\text { Volume X Strength }) \text { of } \mathrm{KOH}}{\text { Weight in grams of sample taken }}
$$

\section{Determination of the ester value of the Aegle marmelous:}

The ester value is the number of milligrams of potassium hydroxide required to react with the esters in $1 \mathrm{~g}$ of a fat or oil. Triglycerides (fats and oils) are important raw materials in the preparation of soaps. Three measures of quality are the acid value, the saponification value, and the ester Value. Ester Value = Saponification Value - Acid Value.

The saponification value is the number of $\mathrm{mg}$ of potassium hydroxide required to neutralize the fatty acids resulting from the complete hydrolysis of $1 \mathrm{~g}$ of the substance.

For the saponification value; $5 \mathrm{~g}$ of essential oil is taken in conical flask and pipette out $50 \mathrm{~mL}$ alcoholic $\mathrm{KOH}$ into the flask. Add porcelain chips and connect the flask with air condenser and reflux gently for 30 minutes. Allow cooling and adding phenolphthalein indicator and neutralize the liquid with $0.5 \mathrm{M} \mathrm{HCl}$. Note the volume of $\mathrm{HCl}$ consumed for the neutralization.

\section{Physico - Chemical Parameters}

The Physico - Chemical Parameters determined were as follows: 
J. Nepal Chem. Soc., Vol. 36, 2017

\begin{tabular}{|c|c|c|c|}
\hline SN & Parameters & Results & Methods \\
\hline 1 & Colour & Light white & \\
\hline 2 & Odour & Characteristic & \\
\hline 3 & Oil Percentage & $1.1 \%$ & $\begin{array}{l}\text { hydro-distillation of dried leaves using Clevenger } \\
\text { apparatus, }\end{array}$ \\
\hline 4 & Specific Gravity & 0.93 at $20^{\circ} \mathrm{C}$ & $\begin{array}{l}\text { AOAC } 19^{\text {th }} \text { Edition, } 2012 \text { (Vol. II Ch-41, Page 2-3 } \\
\text { method no. } 985.19\end{array}$ \\
\hline 5 & Refractive Index & 1.534 at $25^{\circ} \mathrm{C}$ & ISO 280:1999(E) \\
\hline 6 & Optical Rotation & $-0.09^{\circ}$ at $23^{\circ} \mathrm{C}$ & $\begin{array}{l}\text { AOAC } 19^{\text {th }} \text { Edition, } 2012 \text { (Vol. II Ch-36, Page 19- } \\
\text { 20method no. } 920.142\end{array}$ \\
\hline 7 & Acid Value & 2.4 & ISO 1242:1999(E) \\
\hline 8 & Ester Value & 17.7 & $\begin{array}{l}\text { British Standard methods of tests for essential oils } \\
\text { (1953) }\end{array}$ \\
\hline
\end{tabular}

\section{Results and Discussion}

The oil was obtained by conventional hydro distillation of fresh leaves of Aegle Marmelous in a Clevenger apparatus. The oil percentage obtained was $1.1 \%$ on fresh weight basis. Physico - chemical parameters (Specific Gravity: 0.93, Refractive Index: 1.534 at $20{ }^{\circ} \mathrm{C}$, Optical Rotation: $-0.09^{\circ}$ at $20{ }^{\circ} \mathrm{C}$, Acid Value: 2.4 and Ester Value: 17.7 ) were determined.

\section{Conclusions}

We conclude that the essential oil of Bael leaves has very less work and can be isolated by simple hydrodistillation method with high potential for medical purpose. Thus the chemical composition and other physio-chemical parameters were studied.

\section{Acknowledgements}

The author is Thankful to Chief of Natural Product Research Laboratory for Laboratory help and Mr. Laxman Bhandary, Mr. Bhawani Adhikari, Mr. Buddhi. R. Dhital are also thankful for assisting in research work.

\section{References:}

1. P.C. Sharma, V. Bhatia, N. Bansal, A. Sharma, "A Review on Bael Tree". Natural products resources, 2007; 6(2): 171-78.

2. D. Nema, S.K. Srivastava, "Isolation Some Pigment from Stem Bark of the A. Marmelos". Phy.Sci. 1991; 61(8); 452-467.

3. G.N. Sharma, S.K. Dubey, N. Sati, J. Sanadya, "Phytochemical Screening and Estimation of Total Phenolic Content in A. marmelos Seeds", IJPCR, 2011; 3 (2), 27-29.

4. G.N. Sharma, S.K. Dubey, N. Sati, "Evaluation of Germination Power of Aegle marmelos Seeds" J. Chem. Pharma. Res. 2011, 3 (1): 732-736.

5. K. Sharma, E.S. Chauhan, "Nutritional and Phytochemical Evaluation of Fruit Pulp Powder of Aegle marmelos (Bael), JCPS, 2017, 10 (2)73-76.

6. A. Vaibhav, O.P. Singh, "Evaluation of Therapeutic Potential of A. marmelos Leaves in Metabolic Syndrome. JIPR, 2016, 6 (6), 5836-5841.

7. V. L. Singleton, J. A. Rossi, Am. J. Enol. Vitic., 1965, 16, 144-158. 